\title{
SECURITY CULTURE AT PRODUCTION FACILITY. CONCLUSIONS FROM EMPLOYEES' TRAINING
}

\author{
doi: 10.2478/cqpi-2019-0003 \\ Date of submission of the article to the Editor: 02/05/2019 \\ Date of acceptance of the article by the Editor: 29/05/2019
}

Karolina Wojtasik ${ }^{1}$ - orcid id: 0000-0002-1215-5005

1 University of Silesia - Poland

\begin{abstract}
A high level of safety culture is a factor affecting the quality of production. The article contains conclusions and recommendations regarding creating a safety culture based on the awareness of threats and the ability to respond to them. The aim of the article is to analyze trainings on AT (antiterrorist) security procedures conducted in critical infrastructure $(\mathrm{Cl})$ enterprises and enterprises which are subject to mandatory protection. The theoretical system of reference is based on the issues regarding security culture and sociology of work. Observation of employee training, followed by analysis of employees' behavior and interviews with their supervisors, allowed to assess the functionality of solutions and develop recommendations for the training of with and blue collar workers.
\end{abstract}

Keywords: staff training, safety procedures, critical infrastructure $(\mathrm{Cl})$, mandatory protection, anti-terrorism, security culture

\section{INTRODUCTION}

The critical infrastructure $(\mathrm{Cl})$ and enterprises which are subject to mandatory protection has an important place in Polish security system. These facilities play a crucial role in the proper functioning of a state and the life of society. However, they are susceptible to destruction, damage and disruption, which may be caused by forces of nature or human actions. That is why high level of security culture in these facilities are so important. As a result of the entry into force of the Anti-terrorism Act from 10 June 2016 (Journal of Laws [Dz. U.], item 904), the current procedure of security plan acceptance was extended to include participation of the Internal Security Agency through the requirement to submit a so-called anti-terrorist attachment. It is crucial to train employees at antiterrorist procedures and teach how to act in dangerous situations. In Poland, country stereotypically regarded as safe from terrorism that kind of training has become a challenge. The author described her experiences related to the process of preparations as well as conclusions based on employee trainings conducted in workplaces where anti-terrorism procedures were implemented. The aim of the article is to assess the functionality of solutions and develop recommendations for the training of white and blue collar workers. 


\section{THEORETICAL SYSTEMS OF REFERENCE: SECURITY CULTURE}

A workplace is a social system that is binded by organizational culture, which is created (more or less consciously) by employees (Suchacka, 2017). The organizational culture of the enterprise is made up of social norms and systems of values stimulating employees, the proper organizational climate, management methods, shared meanings and symbols, cognitive patterns, and behavioral requirements (Nogalski, 1998). Organizational culture is a system of thinking patterns and actions that are embedded in the social environment of the organization and are important for achieving its formal goals (Sikorski, 2002). The culture of the enterprise as a system of the most important meanings and beliefs of its members over the years is not only shaped by human views, ways of thinking and behavior, but also defines and controls the behavior of the organization's participants. Each organization produces certain specific, internal procedures, ways of communicating its members and symbols that modify the way it functions (Rapacki, 1995).

There are as many different organizational cultures as many there are enterprises, because each organization shapes and creates its identity differently. Organizational culture in a passive and unconscious way is taken over by members of the organization over time. Employees, based on the rules and customs prevailing in the enterprise, instill in them loyalty, respect for values, norms and customs prevailing in the organization, implying desirable behavior patterns common to all staff. The more employees identify with the company's values the process takes place faster, because they duplicate patterns that seem to them the only right and proper way to proceed. The low level of organizational culture translates into the preservation of negative patterns in employees' awareness, becoming at the same time a barrier against attempts to change this state (Ejdys, 2010). Quality culture and safety culture are subsets of the broadly understood organizational culture (Wolniak and Olkiewicz, 2019).

The company's security culture is a state of awareness of hazards and threats characteristic for most crew, formal and informal procedures that are implemented in emergency situations, as well as technical and organizational achievements that affect the safety and health in company management, task organization, supervision and evaluation of employees (Ejdys, 2010). Security culture is a component of organizational and social culture and all collective actions involving the use of organizational and inter-organizational practices that aim to protect the individual employee and the entire working environment; it is also a set of values and beliefs within the organization that create specific patterns of behavior. (Glaspie and Karwowski, 2017; Buluc et al., 2018). Organizations with a high level of health and safety culture are characterized by a communication system based on real trust, perceiving the importance of security issues and respecting preventive measures. The involvement of managers and employees in activities for health and safety is a key factor in shaping culture. The level of safety culture can be assessed through the attitudes and behavior of members of a given organization, which depend on the adopted system of values and beliefs. On the one hand, human behavior depends on the security culture, on the other hand, it is human behavior that shapes culture by perpetuating certain attitudes.

Respondents in the research conducted on a group of 76 representatives of enterprises (Ejdys, 2010) most often stated that a high level of safety culture in an organization can be recognized after: an appropriate system of training employees 
shaping their awareness; compliance with legal provisions of health and safety for both employers and employees; visible marking system - communication routes, emergency exits, dangerous zones, rooms; safe working conditions; general order and order in the enterprise; the company's system of health and safety procedures and instructions; personal protective equipment used by employees; preventive actions undertaken (medical examinations); ensuring technical safety of machines and devices; liability of the employer and employees for health and safety matters; low accidents; an existing control system in the organization. Security culture is a set of unwritten rules of behavior of the whole, that is in the case of a workplace - all employees, both management, mid-level supervision and handworkers; it is therefore a subset of the general culture of the organization, and its formation is a long-term, multidimensional and continuous stage that covers the entire structure of the enterprise.

The accumulation of efforts to ensure a high safety culture should be the responsibility of especially the top management, because it is them who are responsible for security throughout the enterprise. In the sphere of corporate security culture, it is worth paying attention to several aspects. First, standards and rules for dealing with risk, adopted in a given company. They determine when the risk is significant and requires an appropriate response. On the other hand, they indicate when the risk can be described as acceptable or so small that it does not require any corrective actions. Second, attitudes towards security. They refer to the behavioral sphere of both the individual and social groups on the beliefs related to the validity of security. Thirdly, reflexivity, which consists in learning, that is, the ability to draw conclusions from the results of previously undertaken actions and to respond appropriately to new and unknown threats. An employee in the enterprise is a key and basic link in the efficient and correct functioning of the organization. Even the best designed plant, the technological process, adapted and constructed machines and devices, as well as the most well-established norms and work instructions will not fulfill the role if the employee fails. Therefore, it is important to devote a lot of attention to the formation of appropriate employee attitudes in this field. Shaping a culture of work safety requires long-term and clearly defined tasks, the work safety culture itself requires care, care and fixation in the workplace by all the members of the plant. A special role in this respect is played by the management and employees responsible for training, since it is expected that they will start activities aimed at shaping a security culture (Ejdys, 2010).

\section{MANDATORY PROTECTION AND CRITICAL INFRASTRUCTURE (CI) OF A STATE}

Mandatory protection means: protection of areas, structures, equipment and shipments crucial to the defense and economic interest of the country, public security and other important interests of the country provided by specialist armed units or adequate technical protection, in accordance with the relevant provisions of the People and Property Protection Act from 22 August 1997 (Journal of Laws [Dz. U.] from 2014, item 1099 and from 2015, item 1505). Article 5 of the said act divides areas, structures and equipment into groups according to the following categories: national defense, protection of the economic interest of the country, public security, protection of other important interests of the country and additionally: structures (including buildings), equipment, installations, services included in the uniform list of 
structures, installations, equipment and services which are part of the critical infrastructure. Detailed lists of areas, structures and equipment are prepared by: the President of the National Bank of Poland, National Broadcasting Council, ministers, heads of central offices and governors with respect to subordinated or supervised organisational offices. Inclusion of a given area, structure or equipment in this list is made by means of an administrative decision. Governors keep record of areas, structures and equipment subject to mandatory protection located within a province. Within the territory of the Republic of Poland there are 3490 structures subject to mandatory protection (31 December 2017), of which 368 are located in the Silesian province and an equal number in the Greater Poland province which is the highest number in the country.

According to the Crisis Management Act of 26 April 2007 (Journal of Laws [Dz. U.] from 2013 item 1166 and from 2015 item 1485), critical infrastructure consists of systems and its constituent functional facilities, including structures, equipment, installations, services which are crucial to the security of a state and its people and which ensure the effective functioning of public administration, institutions and businesses. Critical infrastructure includes systems related to: energy supply, energyproducing raw materials and fuels, communications, IT networks, finance, food and water supply, health protection, transport, medical emergency response, continuity of public administration, production, holding, storage and use of chemical and radioactive substances including pipelines for dangerous substances. $\mathrm{Cl}$ consists of physical and software systems (facilities, equipment and installations) necessary for basic functioning of the economy and country. Not every strategic facility is a part of critical infrastructure. The decision of inclusion of a given facility in the $\mathrm{Cl}$ is based on detailed criteria specified in a classified attachment to the National Programme for Critical Infrastructure Protection (2018). Cl facilities play a crucial role in the proper functioning of a state and the life of society (Wojtasik et al., 2019).

An administrator of a facility which is $\mathrm{Cl}$ or subject to mandatory protection is obliged to prepare and submit to the correct division of the Internal Security Agency the socalled anti-terrorist attachment, i.e. protection scheme of a structure (area or equipment) in respect of terrorist threats. All the employees should be made familiar with procedures and instructions included in mentioned document.

\section{AT TRAINING - STUDY ASSUMPTION}

In 13 production facilities and headquarters (5 groups) of company $X$, safety trainings were conducted. The analysed facilities differed in terms of production specifics, size of the occupied area, number of buildings/equipment situated in the facility, number of employees and the number of specialised security and protection (SUFO/WSO) employees. Around 100 white-collar workers (specialists, department heads, production plant managers, office workers) and about 800 workmen were trained, as well as security employees. The production facilities belonging to company $X$ are subject to mandatory protection (some of them are $\mathrm{Cl}$ ), therefore they should be familiarized with the procedures included in the anti-terrorist (AT) attachment to the protection plan (Wojtasik et al., 2019). At the stage of training planning, potential problems were identified and difficulties were diagnosed: 1 . large training groups; 2 . a significant group of employees disregarding the topic, convinced that AT training is unnecessary, lack of awareness of security threats among the workers; 3 . the necessity of removing employees from their tasks (trainings were held during working 
hours); 4. employees participate in many trainings (but different subjects), they feel excess, 5 . low level of knowledge related to safety and security; 6 . training could turn into a discussion forum on security-related topics, which are not the subject of training. A chance was definitely the fact that no similar trainings were organized before, trainings were run by company employees, not by an external entity, trainings included current topics, and the form of trainings enabled practical demonstrations. Literature analysis above shows the key role of security culture in the proper functioning of the workplace. An important element is the existence of procedures for dealing with threats (AT attachment), but above all the system of employee training, so that the procedures contained therein become an important element of the everyday life of the employees of the production plant. The research included interviews with trainers, interviews with supervisors of groups of employees, as well as participant observation during training (the researcher was present at all 18 trainings ) and analysis of training materials. The aim of the research is to develop recommendations and conclusions and to identify good practices in training employees at AT procedures.

\section{CONCLUSIONS AND RECOMMENDATIONS}

First of all, the awareness of threats and knowledge of AT procedures in Polish society is low. Employees of company $X$ are no exception, so AT training is necessary. The crew is not aware of terrorist threats and react with a smile of pity, stressing the nonsense of conducting this type of training in a safe country. The lack of education for safety and security at the extra-curricular level means that the specialists training the crew from the procedures included in the AT attachment should have the necessary so-called soft competences - the ability to focus attention, interpersonal skills, the ability to relieve negative emotions, an interesting way of presenting the subject, well-mastered non-verbal communication, so as to overcome the reluctance of part of the crew. Secondly, training in AT procedures without showing threats, using examples from Polish soil is ineffective. Police statistics, photos, specific cases, descriptions of real events should be part of the training. Without presenting real threats in Poland, the training will be taken by employees negatively, as knowledge that will never be useful. Thirdly, in the analyzed cases, the trainers decided to include in the training topics related to everyday life, e.g. using legal devices for self-defense (personal alarm, stun gun, telescopic baton, pepper spray), demonstrating them, discussing the advantages and disadvantages, showing how to use them safely, show the difference between weapons and devices for selfdefense. This knowledge has a practical dimension, generates questions, activates listeners, because in the course of the discussion it turns out that many employees feel the need to have them, but they do not know how to use them. Employees feel then that the knowledge transferred during training is useful. In addition, the topics related to avoiding of a robbery or physical attack attempt are very popular among the crew, as is the lecture on the most popular techniques and methods of car theft. Employees who understand the meaning of safe behaviors in everyday life, better absorb AT procedures at on-the-job training. Fourthly, the trainings also aim at broadly understood education for safety and making the society familiar with appropriate attitudes and reactions to IED (improvised explosive device) in public space, the attack of an active shooter or evacuation procedures. The trainings also teach how to behave in an hostage situation and what not to do when the AT team 
enters the scene. A quick noticed IED in a public space means a chance to neutralize it without human harm, effective evacuation is the key to survival. Training should teach civic attitudes, pay attention to the environment and the potential threat situation, because citizens are, along with the police and uniformed services, an element of the security system of the state. Fifth, training on AT procedures is designed to increase the vigilance of employees in the workplace, teach them to pay attention to unfamiliar people, notice objects of unknown origin, etc., Moreover, they are taught to report any irregularities to security staff, and made familiar with behaviors important for increasing the level of safety on a daily basis, not only in an emergency situation. Therefore, properly conducted training for employees results in strengthening the safety culture, but also affects the quality of production. Seventh, trainings organize knowledge in the field of notification in emergency situations, employees know who to turn to, know the competences of security staff and learn to treat it as a helping hand, not a necessary evil. Eighth, the competence and knowledge of trainers, which should have first of all specialist knowledge in the field of security, anti-terrorism, terrorist activities and the modus operandi of the assassination offenders, are extremely important, so as to realize that the threat is not illusory and correctly applied AT procedure it can save employees' lives. Ninth, in the analysed cases, the training related to the AT attachment procedures covers not only the rules of evacuation form a workplace premises but also the general rules on how to behave in a dangerous situation, for example instructions on what to do with a suspicious package, the Run, Hide, Fight rule and developing correct reactions and reflexes; that knowledge can save a life, which should be emphasized by the trainers. Tenth, training of AT procedures is a challenge for the management of the enterprise (making a decision about training), employees (readiness to participate), trainers (skills, knowledge, competences). This project will not succeed without proper communication between all participants in the process. Eleventh, training at AT and safety procedures is one of the elements building security culture and should be extended with practical exercises for the entire crew.

\section{REFERENCES}

Buluc, R., Lungu, C., Deac, I., 2018. Perceptions On Security Culture, $7^{\text {th }}$ International Conference on Redefining Community in Intercultural Context, RCIC '18. - Nation Branding, Identity and Security, Bucharest, Editura Acad Fortelor Aeriene Henri Coanda, 149-156.

Crisis Management Act of 26 April 2007 (Journal of Laws [Dz. U.] from 2013 item 1166 and from 2015 item 1485

Ejdys, J., (ed.) 2010. Kształtowanie kultury bezpieczeństwa i higieny pracy w organizacji, Oficyna Wydawnicza Politechniki Białostockiej, Białystok

National Programme for Critical Infrastructure Protection (2018); https://rcb.gov.pl/wpcontent/uploads/Dokument-G\%C5\%82\%C3\%B3wny-1.pdf

Glaspie, HW, Karwowski W., 2017. Human Factors in Information Security Culture: A Literature Review, AHFE International Conference on Human Factors in Cybersecurity, Los Angeles, Springer International Publishing AG, 269-280.

Nogalski, B., 1998. Kultura organizacyjna. Duch organizacji, Oficyna Wydawnicza Ośrodka Postępu Organizacyjnego, Bydgoszcz 
People and Property Protection Act from 22 August 1997 (Journal of Laws [Dz. U.] from 2014, item 1099 and from 2015, item 1505)

Sikorski, Cz., 2012. Kultura organizacyjna, C. H. Beck, Warszawa

Suchacka, M., 2017. Wybrane aspekty doskonalenia kultury organizacyjnej w kontekście bezpieczeństwa pracy, in: Światowy dzień bezpieczeństwa i ochrony zdrowia w pracy, (ed.) Ulewicz, R., Żywiołek, J., Oficyna Wydawnicza Stowarzyszenia Menedżerów Jakości i Produkcji, Częstochowa, 67-84

Wojtasik, K., Grochowski, M., Horák, V., 2019. System and Human Safety: Critical Infrastructure and Anti-Terrorist Attachment, System Safety: Human - Technical Facility - Environment, 1 (2019), s. 894-901, DOI: https://doi.org/10.2478/czoto2019-0114

Wolniak, R., Olkiewicz, M., 2019. The relations between safety culture and quality culture, System Safety: Human - Technical Facility - Environment, 1 (2019), s. 10-17 DOI: https://doi.org/10.2478/czoto-2019-0002

https://www.abw.gov.pl/

http://www.policja.pl/pol/kgp/biuro-prewencji/wydzial-nadzoru-nad-sp/specjalistyczneuzbroj/76255,Liczba-obiektow-podlegajacych-obowiazkowej-ochronie.html https://rcb.gov.pl/infrastruktura-krytyczna/ 